\title{
Effects of selected pre-emergence herbicide-treated oil palm residues on goosegrass emergence and growth
}

\author{
Tse-Seng Chuah ${ }^{\mathrm{a} *} \odot$, Win-Kent Lim ${ }^{\mathrm{b}}$ \\ a Universiti Teknologi MARA, Perlis Branch, Arau, Perlis, Malaysia. ' University of Malaysia Terengganu, Kuala Terengganu, Terengganu, Malaysia.
}

\begin{abstract}
Background: Goosegrass, one of the problematic weeds in the world. Various herbicides have been widely employed for goosegrass control. However, heavy reliance upon the herbicides has led to the evolution of herbicide-resistant biotypes of goosegrass. Diversified approach is needed for sustainable management of goosegrass.

Objective: Evaluate the phytotoxicity of selected preemergence herbicidetreated oil palm residue powders on goosegrass emergence and growth.

Methods: A glasshouse experiment was arranged as complete randomized design with five replications. The oil palm residue powders; leaflet (OPL), rachis (OPR) or frond (OPF, leaflet + rachis) were treated with preemergence herbicides, viz S-metolachlor, oxyfluorfen or thiobencarb at their respective ED50 rates (rate that gives 50\% inhibition) and applied as
\end{abstract}

mulches. The analyzed variables were emergence and shoot fresh weight of goosegrass seedlings.

Results: The ED97 value (rate that causes 97\% inhibition) of S-metolachlor for growth of goosegrass was reduced by more than $90 \%$ when being mixed with the oil palm residue powders. Similarly, the ED97 value of thiobencarb was reduced by $90 \%$ when goosegrass was treated with thiobencarb-treated OPF powders. By contrast, the oxyfluorfen-treated oil palm residue powders and thiobencarb-treated OPL or OPR powders provided lower inhibitory effect on the goosegrass.

Conclusions: Oil palm residues of leaflets, rachis and fronds have potential to reduce rate of preemergence herbicide to inhibit goosegrass seedling emergence and growth depending on herbicide choice and parts of oil palm frond used.

Keywords: Emergence; Integrated weed management; Physio-chemical weed control; Shoot fresh weight; Eleusine indica (L.) Gaertn

Journal Information:

ISSN - 2675-9462

Website: http://awsjournal.org

Journal of the Brazilian Weed

Science Society

How to cite: Chuah TS, Lim WK. Effects of selected pre-emergence herbicide-treated oil palm residues on goosegrass emergence and growth. Adv Weed Sci. 2021; e21234162.

https://doi.org/10.51694/AdvWeedSci/2021;39:00008

Approved by:

Editor in Chief: Carlos Eduardo

Schaedler

Conflict of interest: The authors declare that there is no conflict of interest regarding the publication of this manuscript.

Received: February 17, 2020

Approved: March 9, 2021

* Corresponding author: <chuahts@uitm.edu.my>

\section{(c) (1)}

This is an open-access article distributed under the terms of the

Creative Commons Attribution License, which permits unrestricted use, distribution, and reproduction in any medium, provided that the original author and source are credited.

Copyright: 2021

\section{Introduction}

Goosegrass (Eleusine indica) is one of the most troublesome weeds in the world (Holm et al., 1997) and is commonly found in vegetable farms, orchards, immature oil palm plantations (Chuah and Ismail, 2010) and aerobic rice fields (Chauhan, 2012). Additionally, goosegrassis documented as one of the most difficult turfgrass weeds to be controlled in the tropical and subtropical regions because the seedheads are typically present throughout the year (Wieclo, 2000). Goosegrass is tolerant to a wide range of salt stress and $\mathrm{pH}$ (Chauhan and Johnson, 2008) and water stress (Ismail et al., 2002, 2003). Goosegrass seed buried at 2, 10, and $20 \mathrm{~cm}$ depths in soil showed 39, 33, and 79\% viability, respectively after 2 years (Chuah et al., 2004a). Goosegrass can be controlled by a wide range of preemergence and postemergent herbicides including MSMA plus metribuzin (James et al., 2009), sethoxydim plus fluazifop-butyl (Chuah et al., 2004b), ametryn plus glyphosate or glufosinate (Chuah et al., 2008), prodiamine (Wieclo, 2000), oxadiazon and sulfentrazone (Brecke et al., 2010), foramsulfuron (Philip, 2004), nicosulfuron (McCullough et al., 2012) and indaziflam (Perry et al., 2011). However, the synthetic herbicides alone cannot provide long term weed control because heavy dependence on the herbicides has resulted in the evolution of goosegrass herbicide resistance since 1973. Goosegrass is reported to be resistant to different groups of herbicides such as glyphosate, paraquat, glufosinate, trifluralin, metribuzin, imidazolinones, oxdiazon, aryloxyphenoxyproprionates and cyclohexane (Heap, 2020) This resistance problem limits herbicide option in controlling the goosegrass infestation. Therefore, alternative weed management strategies should be employed to overcome such resistance problems and effective control of goosegrass.

One of the alternative strategies might be through the application of organic mulches. Organic mulches can help in reducing the weed germination and suppressing weed growth through physical and chemical barriers. However, Skroch et al. (1992) found that the mulch cover alone was not sufficient to provide commercially acceptable level of weed control. Therefore, preemergence herbicides have been proposed to be incorporated with organic mulches to increase weed control efficacy. According to Case and Mathers (2003), mulches pretreated with preemergence herbicides may extend the weed control over 300 days as compared with bare ground herbicide application, where the control efficacy lasted only 45 days. However, previous research on the interaction between the crop residues and herbicides showed mixed results, from no 
interaction to antagonism (Chauhan and Abugho, 2012) or potential synergism (Teasdale et al., 2005), depending on type and rate of herbicides and crop residues used.

Malaysia is the second largest producers of palm oil (Elaeis guineensis Jacq.) in the world, with total planted acreage of 5.04 million ha (MPOB, 2019). According to Khalid et al. (1999), million tons of oil palm fronds were produced during routine pruning and replanting season. Oil palm fronds can be processed into animal feeds or paper pulp, but the excessive are left as mulch between oil palm trees for weed suppression and nutrient recycling purpose (Elbersen et al., 2005). Nevertheless, the testing of oil palm fronds for weed management still warrants further investigation.

This study was carried out by treating oil palm residues with selected pre-emergence herbicides (S-metolachlor, oxyfluorfen, and thiobencarb), which are commonly used in vegetable farms and rice fields for weed control. These herbicides were selected because goosegrass has not evolved resistance to the herbicides (Heap, 2020). Oil palm residues were examined since the residues like oil palm fronds are abundant during routine pruning and replanting season. Herbicide-treated mulch could be an option for long-term weed control that incorporates two weed control methods. Combining physical (mulch) and chemical (herbicide) control methods could reduce the herbicide usage, thus slowing down the evolution of weed resistance to herbicide. This study aimed to evaluate the effect of oil palm residues incorporated with selected preemergence herbicides on seedling emergence and growth of goosegrass.

\section{Material and methods}

\subsection{Herbicides}

The herbicides used were S-metolachlor (Dual Gold 960 EC, 87.3\% w/w, Syngenta Crop Protection, Selangor, Malaysia), oxyfluorfen (BOXY EC, 24.3\% w/w, Zeenex AgroScience, Kuala Lumpur, Malaysia), and thiobencarb (SATURN 50 EC, 50\% w/w, Agricultural Chemicals, Penang Island, Malaysia).

\subsection{Plant materials}

Oil palm (Elaeis guineensis var. Tanera) fronds were collected from an oil palm plantation in Setiu, Terengganu, Malaysia. The fronds (OPF) were cleaned and dried under full sunlight for a week and kept in an oven at $50{ }^{\circ} \mathrm{C}$ for a week. Then, the fronds were divided into two groups; one group was ground into powder form $(<2 \mathrm{~mm})$ using a mill grinder and stored in a chiller at $5{ }^{\circ} \mathrm{C}$ before use while the other group was separated into leaflet (OPL) and rachis (OPR) before being ground. The goosegrass seeds were collected around roadsides of Gong Badak, Kuala Terengganu, Malaysia. Seed viability of goosegrass was examined to ensure the seeds had germination percentage higher than $90 \%$. Seed coats of the goosegrass seeds were removed by using sand papers.

\subsection{Growth medium}

Silt loam soil (sand: silt: clay- 70.2: 26.8: 3.0\%; organic carbon $3.5 \%$; $\mathrm{pH}$ 5.5) used in this study was sampled from a coconut plantation at Agricultural Research and Development Institute of Malaysia (MARDI), Hilir Perak Station, Teluk Intan, Malaysia. The soil was sun-dried and sieved to pass through a 2-mm screen. Fifty grams of soil was filled in each cup (4-cm diameter, $5-\mathrm{cm}$ height) with five holes at the bottom.

\subsection{Experiment 1: Application of pre-emergence herbicides or oil palm frond powders}

A total of 20 goosegrass seeds were sown evenly on the surface of soil in each cup and irrigated daily under glasshouse conditions with relative humidity of $85 \%$, a temperature of $39{ }^{\circ} \mathrm{C}$, and $12 \mathrm{~h}$ photoperiod at a light intensity of $800-1,000 \mu \mathrm{molm}^{-2} \mathrm{~s}^{-1}$. Three pre-emergence herbicides were applied at different rates one day after the seeds were sown: S-metolachlor at 0, 12.5, 25.0, 50.0, 100.0, and 200.0 gai ha $^{-1}$; oxyfluorfen at $0,1.2,46.9,18.8$, and $75.0 \mathrm{~g}$ ai ha ${ }^{-1}$ and thiobencarb at 15.63, 62.5, 250.0 and $1,000 \mathrm{~g}$ ai ha $\mathrm{a}^{-1}$.With the same technique, oil palm leaflet, rachis and frond powders were distributed evenly on the soil surface at rates of $0,0.75,1.50,3.00$ and $6.00 \mathrm{t} \mathrm{ha}^{-1}$. Number of seedling emergence was counted while shoot fresh weight of goosegrass seedling was measured 30 days after treatment (DAT). Each treatment was replicated five times in a completely randomized design. Seedlings were considered emerged when the shoot lengths were $>2 \mathrm{~mm}$. The data were expressed as percentages of their respective controls as follows:

$$
\mathrm{y}=(\mathrm{xT} / \mathrm{xC}) \mathrm{x} 100
$$

Where, $y$ is shoot emergence rate or shoots fresh weight, $\mathrm{xT}$ is number of seeds with emerged shoots or shoot fresh weight in treatment, and $\mathrm{xC}$ is number of seeds with emerged shoots or shoots fresh weight in control.

\subsection{Experiment 2: Application of preemergence herbi-} cide-treated oil palm residue powders

The rates of oil palm residues or pre-emergent herbicides which provided 50\% inhibition (ED50) of goosegrass emergence and growth obtained from the first experiment were selected in this experiment. Oil palm residue leaflet, rachis and frond powders at their respective ED50 rate were treated with ED50 rate of oxyfluorfen, S-metolachlor or thiobencarb, respectively. Applications were made using a compression sprayer (Matabi Style 7; Goizper, Bergara, Spain) equipped with flat-fan nozzles calibrated to deliver a volume of $450 \mathrm{~L} \mathrm{ha}^{-1}$ for S-metolachlor and oxyfluorfen while 
$300 \mathrm{~L} \mathrm{ha}^{-1}$ for thiobencarb at $200 \mathrm{kPa}$. The residues were dried for 24 hours under glasshouse conditions. Each type of herbicide-treated oil palm residue powder was applied evenly on soil surface one day after 20 goosegrass seeds were sown in cups and irrigated daily. Number of seedling emergence was counted while shoot fresh weight was measured at 30 DAT. The treatments were replicated five times in a completely randomized design. Seedlings were considered emerged when the shoot lengths were $>2 \mathrm{~mm}$. The data were expressed as percentages of their respective controls as described above. All the above experiments were repeated for two experimental runs. There was no significant interaction between runs, therefore data were combined over runs.

\subsection{Statistical analysis}

To obtain application rate that gave $50 \%$ inhibition, the data from Experiment 1 were fitted to a logistic regression model, as follows (Kuk et al., 2002):

$$
\mathrm{Y}=\mathrm{d}\left(1+[\mathrm{x} / \mathrm{x} 0]^{\mathrm{b}}\right)
$$

Where, $\mathrm{Y}$ is the shoot fresh weight or shoot emergence of the harvested plants, $d$ is the coefficients corresponding to the upper asymptotes, $\mathrm{b}$ is the slope of the line, $\mathrm{x} 0$ is the herbicide or oil palm residue powder rate required to reduce the shoot fresh weight or shoot emergence by $50 \%$, and $x$ is the herbicide or oil palm residue powder rate. Regression analyses were conducted to calculate the herbicide or oil palm residue powder rates required to reduce the shoot fresh weight or shoot emergence by $50 \%$.

The data of Experiment 2 were tested for the normality and homogeneity of variance before being subjected to one-way analysis of variance (ANOVA), followed by Tukey's test to compare treatments means at $5 \%$ level of significance.

\section{Results and discussion}

At a rate of $0.75 \mathrm{t} \mathrm{ha}^{-1}$, oil palm leaflet (OPL), oil palm rachis (OPR) and oil palm frond (OPF) powders had negligible effect on goosegrass seedling emergence. However, when the rate of oil palm residue powder was increased from 1.5 to $3.0 \mathrm{t} \mathrm{ha}^{-1}$, the seedling emergence was inhibited by $60-70 \%$. The rates required for $50 \%$ reduction (ED 50) of the seedling emergence ranged from 2.4 to $2.6 \mathrm{t} \mathrm{ha}^{-1}$ for OPL (Figure 1A), OPR (Figure 1B) and OPF powders (Figure 1C). In a previous study, a combination of rice leaf and straw residue at a rate of $3 \mathrm{t}$ $\mathrm{ha}^{-1}$ has been reported to inhibit the goosegrass seedling emergence by $46 \%$ (Chauhan and Abugho, 2013). In the present study, goosegrass shoot fresh weight was reduced by $60-80 \%$ when the highest application rate, $3 \mathrm{t} \mathrm{ha}^{-1}$ of oil palm residue powder was applied. This finding implies that OPL, OPR and OPF are more phytotoxic to goosegrass than leaf and straw residue of rice plants
A total of 2.1 to $2.5 \mathrm{t} \mathrm{ha}^{-1} \mathrm{OPL}$ (Figure $2 \mathrm{~A}$ ), OPR (Figure 2B) and OPF (Figure $2 \mathrm{C}$ ) powders were needed to provide $50 \%$ inhibition of goosegrass shoot weight (Figure 2). Uwah and Iwo (2011) have demonstrated that $4 \mathrm{t} \mathrm{ha}^{-1}$ Ganba grass (Andropogom gayanus Kunth var. gayanus) mulch reduced $65 \%$ of weed infestation in maize fields. In the present study, the suppressive effect of the oil palm residue powders on goosegrass emergence and growth was rate-dependent (Figures $1 \& 2$ ), suggesting that the incident was due to the release of phytotoxic allelochemicals from the palm residues.

On the other hand, both goosegrass seedling emergence (Figure 3) and shoot fresh weight (Figure 4) declined as the application rate of oxyfluorfen, S-metolachlor, and thiobencarb increased. In order to reduce $50 \%$ emergence

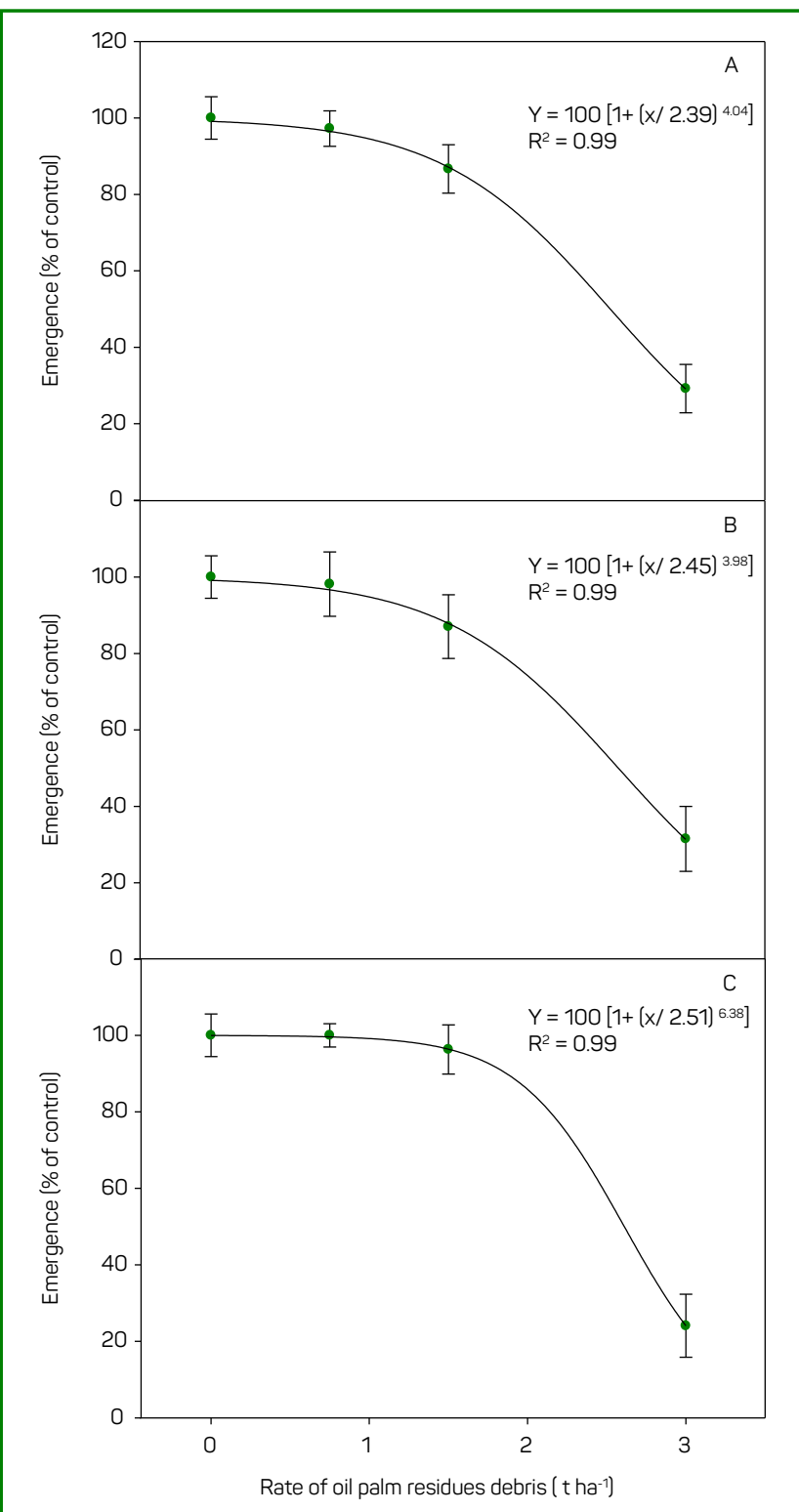

Figure 1 - Preemergence applications of oil palm leaflet (A), rachis (B), and frond (C) powder on the seedling emergence of goosegrass one month after treatment. 
of goosegrass, oxyfluorfen is required at $3.2 \mathrm{~g}$ ai ha- ${ }^{-1}$, S-metolachlor at $30.4 \mathrm{~g} \mathrm{ai} \mathrm{ha}^{-1}$, and thiobencarb at $127 \mathrm{~g}$ ai ha 1. Meanwhile, oxyfluorfen, S-metoloachlor, thiobencarb are required to apply at $1.6,9.5$, and $106.5 \mathrm{~g} \mathrm{ai} \mathrm{ha}^{-1}$, respectively, to achieve $50 \%$ growth reduction in goosegrass. These results suggest that goosegrass is more susceptible to oxyfluorfen than the other preemergence herbicides.

Figure 5 shows the phytotoxicity of oil palm residue powders at their respective ED50 rates in combination with ED50 rates of preemergence herbicides on goosegrass seedling growth and emergence. Both goosegrass seedling emergence and growth were reduced more than 95\% with S-metolachlor-treated oil palm residues. Single application of S-metolachlor at $134 \mathrm{~g}$ ai ha-1is required to inhibit goosegrass growth by $97 \%$ (ED97). This ED97

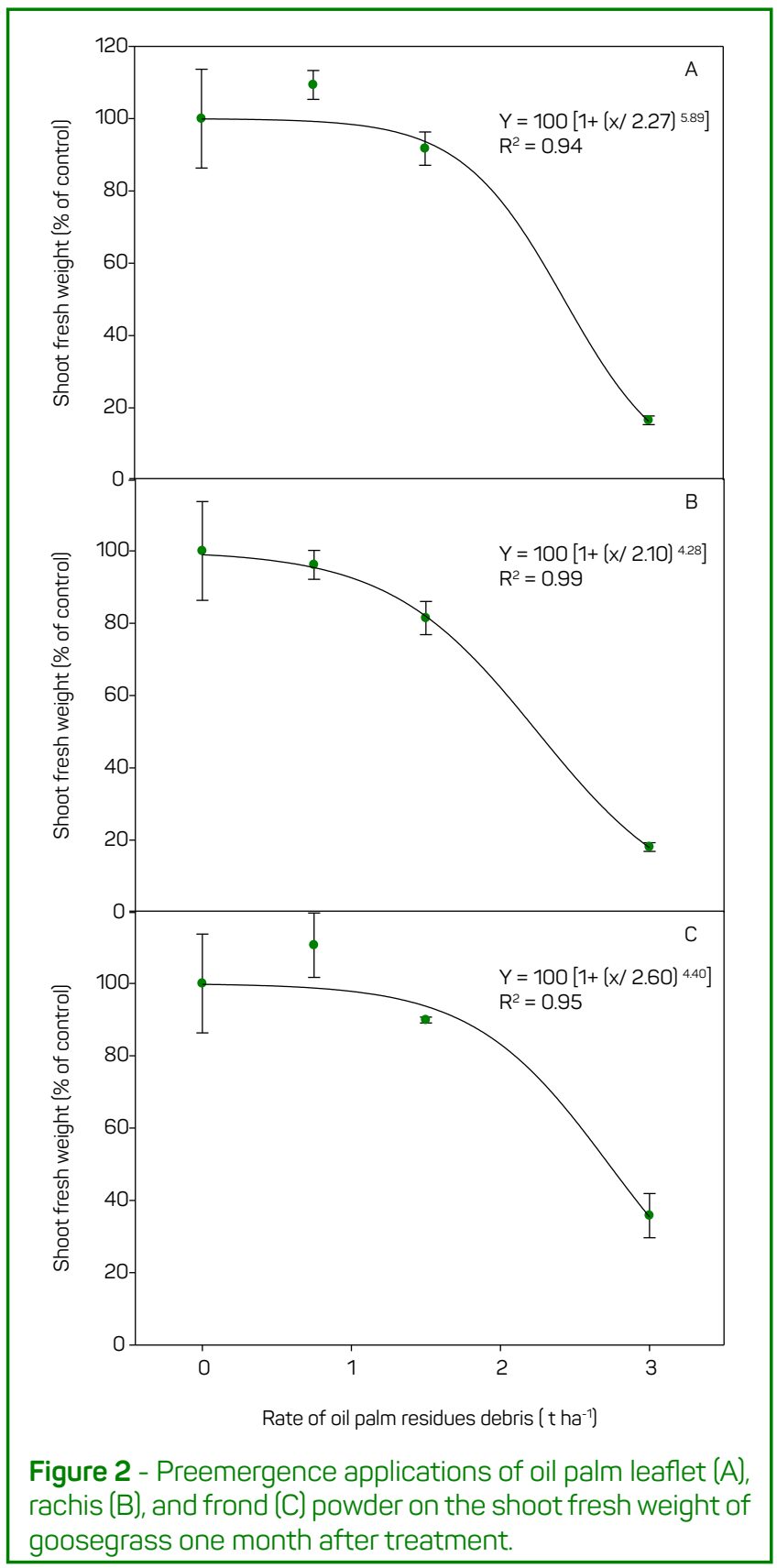

value can be reduced by 14 folds when S-metolachlor was combined with the oil palm residues. This result is in agreement with the finding of Teasdale et al. (2005), where the incorporation of S-metolachlor at $10 \mathrm{~g} \mathrm{ha}^{-1}$ and hairy vetch (Vicia villosa Roth) residue at $5 \mathrm{t} \mathrm{ha}^{-1}$ exhibited synergistic interaction by reducing $86 \%$ of smooth pigweed (Amaranthus hybridus L.) emergence as compared to single application of S-metolachlor which needed approximately $1000 \mathrm{~g}$ ai ha $\mathrm{a}^{-1}$ to achieve the same inhibitory effect.

It has been documented that plant lignin can act as matrix to control the release of herbicides such as diuron and 2,4 D (Oliveira et al., 2000). Lignin contents of OPL, OPR and OPF are high, ranging from $20-30 \%$ (Khalid et al., 2000). This property possibly makes oil palm residue of OPL, OPR or OPF powder a good candidate as slow release

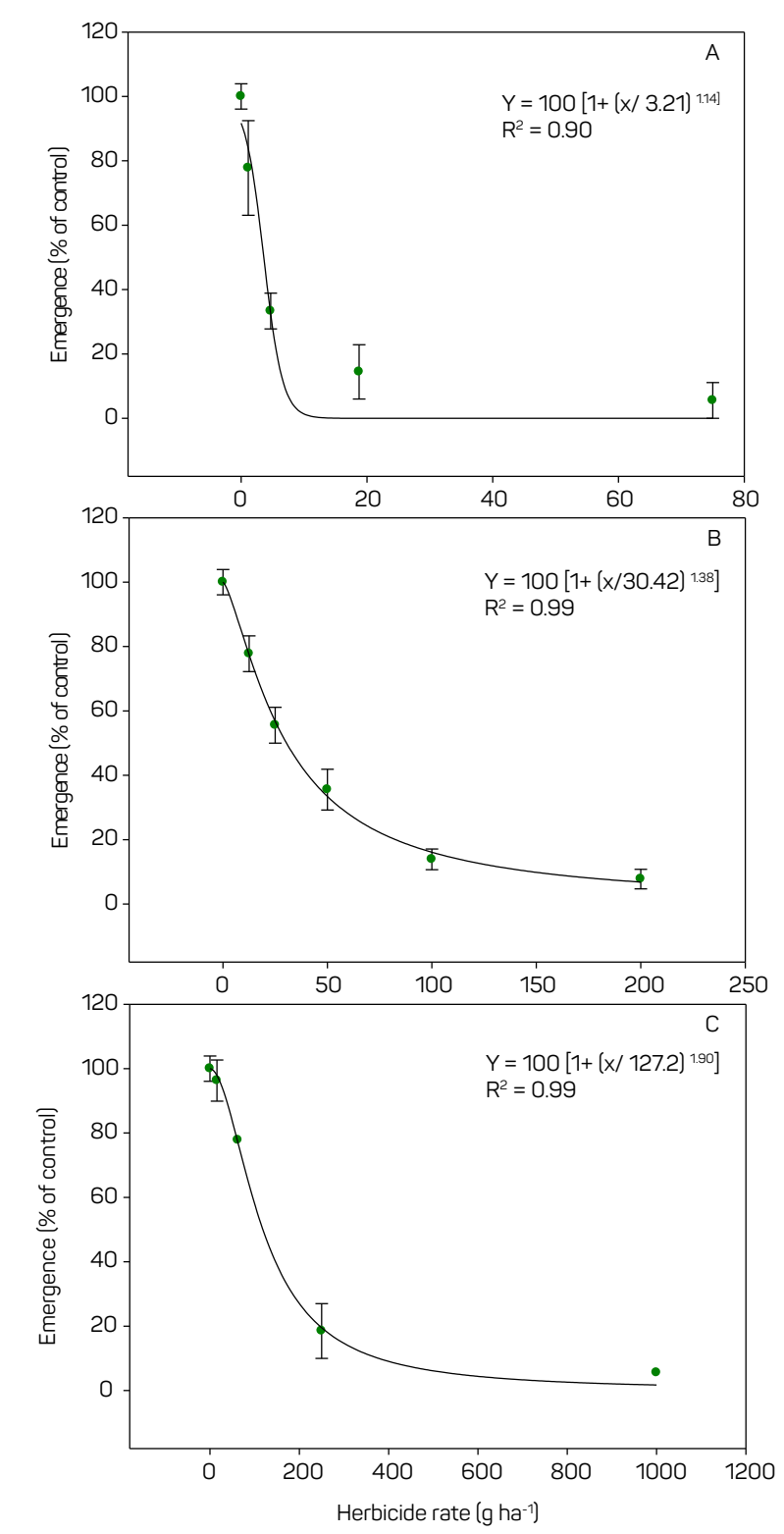

Figure 3 - Preemergence application of oxyfluorfen (A), S-metolachlor (B), and thiobencarb (C) on seedling emergence of goosegrass one month after treatment. 
carrier for S-metolachlor with water solubility of $530 \mathrm{mg}$ $\mathrm{L}^{-1}$ and low $\mathrm{K}$ value of $200 \mathrm{~mL} \mathrm{~g}^{-1}$ (Rivard, 2003), thereby free S-metolachlor molecules are more available in soil for goosegrass seedling uptake. Furthermore, Tharayil et al. (2006) claimed that competition for sorption sites arises if the same sites can be occupied by more than one nonidentical molecule. Allelochemicals released by the oil palm residue powders and metolachlor may be competing for the same sorption sites in the soil. As a result, free S-metolachlor molecules are available for uptake by goosegrass seedlings (Dilipkumar et al., 2012).

On the other hand, thiobencarb in combination with OPL or OPR powders at their respective ED50 rates resulted in 70$80 \%$ goosegrass growth and emergence reduction. Likewise,

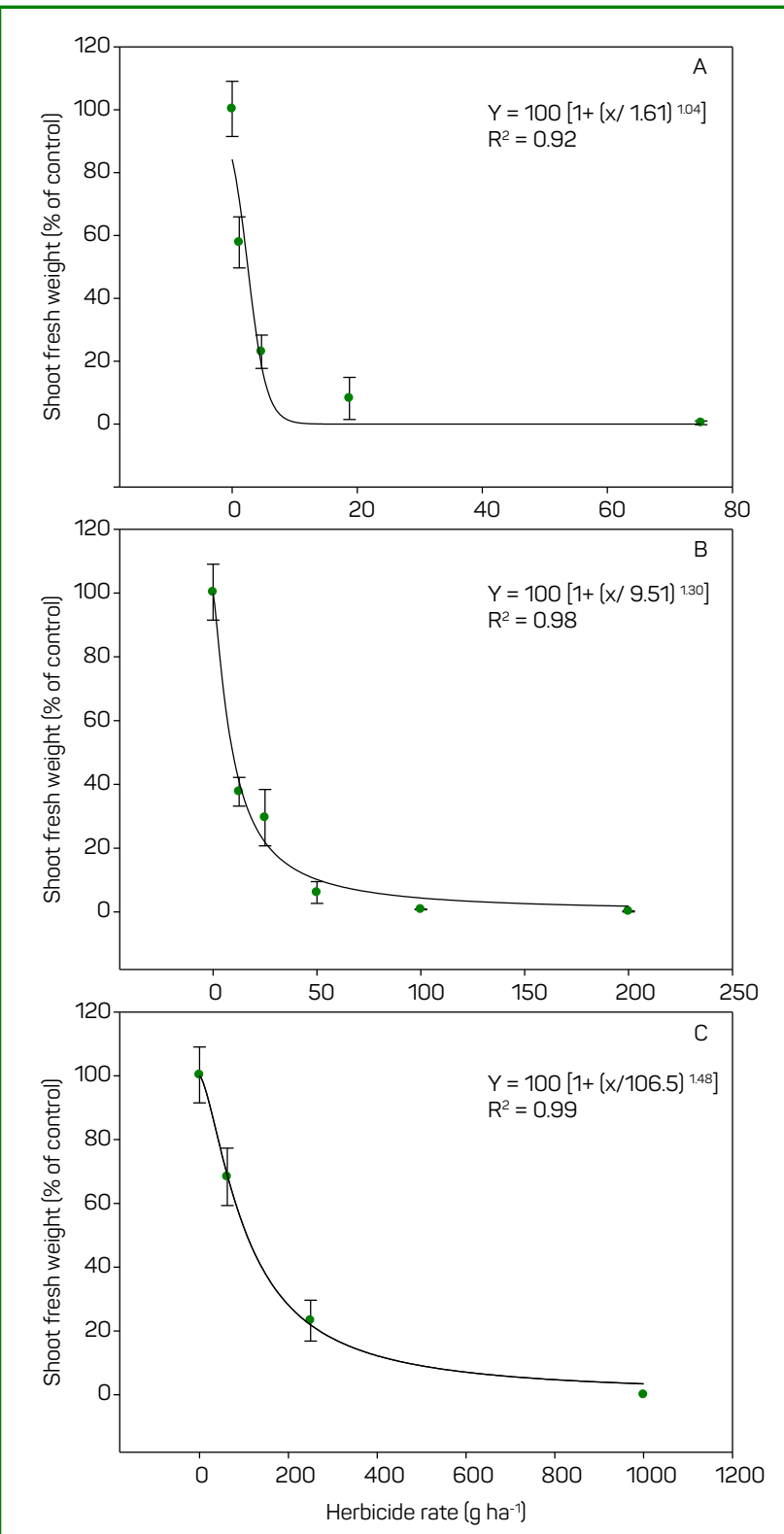

Figure 4 - Preemergence application of oxyfluorfen (A), metolachlor (B), and thiobencarb (C) herbicide on seedling growth of goosegrass one month after treatment. oxyfluorfen-treated oil palm residue powders at ED50 rates only reduced $55-85 \%$ of goosegrass growth and emergence (Figure 5). It is suggested that physical properties of herbicides may contribute to lower efficacy given by oxyfluorfen or thiobencarb-treated oil palm residue powders as compared to those provided by S-metalachlor-treated oil palm residue powders. Water solubility and $\mathrm{K}$ value of thiobencarb are 30 $\mathrm{mg} \mathrm{L}^{-1}$ and $1,380 \mathrm{~mL} \mathrm{~g}^{-1}$, respectively (Ceesay, 2002) while oxyfluorfen has water solubility as low as $0.1 \mathrm{mg} \mathrm{L}^{-1}$ with K value as high as $100000 \mathrm{~mL} \mathrm{~g}^{-1}$ (Wauchope et al., 1992). The lower water solubility of both herbicides is likely to reduce their availability for uptake by goosegrass seedlings. Furthermore, the higher $\mathrm{K}$ values enable these herbicides to have a greater adsorption potential to bind with soil organic matter and soil colloid after they have been slow-released from the oil palm residue powders, thus resulting in less free herbicide molecules for goosegrass uptake. Surprisingly, more than $95 \%$ of goosegrass emergence and growth were suppressed when being subjected to thiobencarb-treated OPF powders at ED50 rates (Figure 5). The OPF powder may contain a blend of allelochemicals derived from the rachis and leaflet of oil palm residue powders. These allelochemicals may act with thiobencarb synergistically by suppressing the seedling emergence and growth of goosegrass. In contrast, Chauhan and Abugho (2012) found that $0.5 \mathrm{~kg} \mathrm{ha}^{-1}$ of oxadiazon application reduced $90 \%$ of barnyard grass (Echinochloa crus-galli (L.) Beauv.) seedling emergence but the application of the same rate of oxadiazon with the addition of $3 \mathrm{t} \mathrm{ha}^{-1}$ rice residue only gave $65 \%$ suppression. Furthermore, application of $1 \mathrm{~kg} \mathrm{ha}^{-1}$ of pendimethalin in the presence of $3 \mathrm{t} \mathrm{ha}^{-1}$ rice residue resulted in lower rice flat sedge (Cyperus iria L.) control than zero residues. This antagonistic

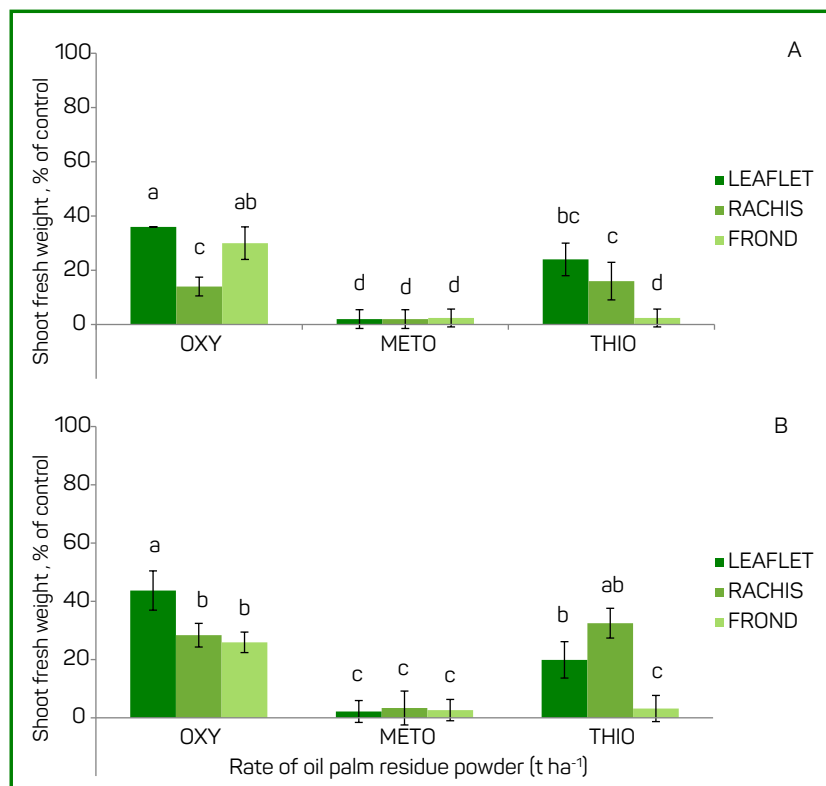

Figure 5 - Phytotoxic effect of oxyfluorfen (OXY), S-metolachlor (METO) and thiobencarb (THIO) -treated oil palm residue of leaflet, rachis and frond powderon seedling emergence (A) and shoot growth (B) of goosegrass one month after preemergence application. 
action may be due to the variable distribution of rice residue on the soil surface, thereby causing some weeds escape from the treatments (Chauhan and Abugho, 2012).

In conclusion, this study has revealed that the oil palm leaflet, rachis and frond residue powders alone can inhibit emergence and growth of goosegrass by $50 \%$ when applied at 2.0 to $2.6 \mathrm{t} \mathrm{ha}^{-1}$. Great or moderate inhibition of goosegrass exhibited by the oil palm residues treated with preemergence herbicide is dependent on the choice of herbicide and parts of oil palm frond used. However, glasshouse results cannot be directly extrapolated to field conditions as efficacy of the herbicide-treated oil palm frond residue powders is likely influenced by environmental factors. Further studies have to be undertaken in aerobic rice fields and vegetable farms to verify potential of oil palm frond residue mulch in reducing the thiobencarb or S-metolachlor rate on control of goosegrass, respectively.

\section{Authors' contributions}

Tse Seng Chuah designed the project and contributed to writing of the manuscript. Win Kent Lim contributed to the implementation of the research, to the analysis of the results to writing of the manuscript.

\section{Acknowledgments}

We would like to thank all the crop protection laboratory staff and glasshouse coordinators at the School of Food Science and Technology, University Malaysia Terengganu for the technical assistance. We express our appreciation to Dr. Vu Thanh Tu Anh for edited this manuscript.

\section{References}

Brecke BJ, Stephenson DO, Unruh JB. Timing of oxadiazon and quinclorac applications on newly sprigged turfgrass species. Weed Technol. 2010;24(1):28-32. Available from: http://doi.org/10.1614/WT-08-065.1

Case L, Mathers $\mathrm{H}$. Long term effects of herbicide treated mulches for ornamental weed control. Proceedings of the $57^{\text {th }}$ Annual Meeting-Northeastern Weed Science Society. Baltimore: Northeastern Weed Science Society; 2003.

Ceesay S. Environmental fate reviews: Thiobencarb. Sacramento: California Department of Pesticide Regulation; 2002 [2014 Apr 21]. Available from: http://www.cdpr.ca.gov/docs/emon/pubs/envfate.htm

Chauhan BS. Weed ecology and weed management strategies for dry-seeded rice in Asia. Weed Technol. 2012;26(1):1-13. Available from: http://doi.org/10.1614/WT-D-11-00105.1

Chauhan BS, Abugho SB. Interaction of rice residue and pre-herbicides on emergence and biomass of four weed species. Weed Technol. 2012;26(4):627-32. Available from: https://doi.org/10.1614/WT-D-1200067.1

Chauhan BS, Abugho SB. Effect of crop residue on seedling emergence and growth of selected weed species in a sprinkler-irrigated zero-till dry-seeded rice system. Weed Sci. 2013;61(3):403-9. Available from: https://doi.org/10.1614/WS-D-12-00147.1

Chauhan BS, Johnson DE. Germination ecology of goosegrass (Eleusine indica): an important grass weed of rainfed rice.Weed Sci. 2008;56(5):699-706. Available from: https://doi.org/10.1614/WS-08048.1

Chuah TS, Salmijah S, Teng YT, Ismail BS. Changes in seed bank size and dormancy characteristics of the glyphosate-resistant biotype of goosegrass (Eleusine indica (L.) Gaertn.). Weed Bio Manag. 2004a;4(2):114-21. Available from: https://doi.org/10.1111/j.14456664.2004.00127.x

Chuah TS, Ismail BS. The status of weed resistance in plantation crops in Malaysia. Planter. 2010;86(1014):615-20.
Chuah TS, Salmijah S, Ismail BS. Efficacy of tank-mix combinations of glyphosate and gramicides on the control of glyphosate resistant and susceptible biotypes of goosegrass (Eleusineindico (L.) Gaertn.). Plant Protec. Q. 2004b;19:130-4.

Chuah TS, Nor Asmah BJ, Cha TS, Hasan SMZ, Ismail BS. The use of reduced rates of herbicide combinations in tank-mixes for goosegrass (Eleusine indica (L.) Gaertn.) control. World Appl Sci J. 2008;5(3):358-62

Dilipkumar M., Adzemi MA, Chuah TS. Effects of soil types on phytotoxic activity of pretilachlor in combination with sunflower leaf extracts on barnyardgrass (Echinochloo crus-galli). Weed Sci. 2012;60(1):12632. Available from: https://doi.org/10.1614/WS-D-11-00075.1

Elbersen H, Dam JEG, Bakker RR. Oil palm by-products as a biomass source: availability and sustainability. Proceedings of the $14^{\text {th }}$ European Biomass Conference. Florence: ETA and Munich, 2005.

Heap I. International survey of herbicide-resistant weeds [cited 2020 Dec 8]. Available from: http://www.weedscience.org/Summary/Species.aspx?WeedID=81. 2020

Holm L, Doll J, Holm E, Pancho J, Herberger J. World weeds: natural histories and distribution. New York: J. Wiley. 1997.

Ismail BS, Chuah TS, Salmijah S, Teng YT. Effect of shade and watering frequency on growth and development of glyphosate-resistant and susceptible biotypes of goosegrass (Eleusineindica (L.) Gaertn.). Plant Protec Q. 2003;18(1):30-4.

Ismail BS, Chuah TS, Salmijah S, Teng YT, Schumacher RW. Germination and seedling emergence of glyphosate-resistant and susceptible biotypes of goosegrass (Eleusineindico [L.] Gaertn.). Weed Bio Manag. 2002;2(4):177-85. Available from: https://doi.org/10.1046/j.14456664.2002.00066.x

James TB, Joseph DF, Micah SW, Greg KB. Efficacy of sodium chloride applications for control of goosegrass (Eleusineindica) in seashore Paspalum Turf. Weed Technol. 2009;23(1):179-83. Available from: https://doi.org/10.1614/WT-08-129.1 
Khalid H, Zin ZZ, Anderson JM. Effect of oil palm residues management at replanting on soil nutrient dynamics and oil palm growth. Proceeding of the PORIM International Palm Oil Congress. Kuala Lumpur: Malaysian Palm Oil Board; 1999.

Khalid H, Zin ZZ, Anderson JM. Decomposition process and nutrient release pattern of oil palm residue. J Oil Palm Res. 2000;12:46-63.

McCullough PE, Barreda DG, Raymer P. Nicosulfuron used with foramsulfuron and sulfentrazone for late summer goosegrass (Eleusine indica) control in bermudagrass and seashore paspalum. Weed Technol. 2012;26(2):376-81. Available from: https://doi.org/10.1614/ WT-D-11-00153.1

Malaysian Palm Oil Brar - MPOB. Oil palm planted area by category [cited 2019 June] Available from: http://bepi.mpob.gov.my/images/ area/2012/Area_summary.pdf.

Oliveira SC, Pereira FM, Ferraz A, Silva FT, Goncalves AR. Mathematical modeling of controlled-release systems of herbicides using lignins as matrices. Appl Biochem Biotechnol. 2000;84-6:595-615. Available from: https://doi.org/10.1385/abab:84-86:1-9:595

Perry DH, McElroy JS, Doroh MC, Walker RH. Indaziflam utilization for controlling problematic turfgrass weeds. Appl Turf Sci. 2011;8(1):1-7. Available from: https://doi.org/10.1094/ATS-2011-0428-01-RS

Philip B. Goosegrass (Eleusine indica) control with foramsulfuron in bermudagrass (Cynodon spp.) turf. Weed Technol. 2004;18(3):634-40. Available from: https://doi.org/10.1614/WT-03-111R1

Rivard L. Environmental fate of metolachlor. Sacramento: Environmental Monitoring Branch; 2003
Skroch WA, Powell MA, Bilderback TE, Henry PH. Mulches: durability, aesthetic value, weeds control, and temperature. J Environ Hort 1992;10(1):43-5. Available from: https://doi.org/10.24266/07382898-10.1.43

Teasdale JR, Pillai P, Collins RT. Synergism between cover crop residue and herbicide activity on emergence and early growth of weeds. Weed Sci. 2005;53(4):521-7. Available from: https://doi.org/10.1614/WS-04$212 R$

Tharayil N, Bhowmik PC, Xing B. Preferential sorption of phenolic phytotoxins to soil: implications for altering the availability of allelochemicals. J Agric Food Chem. 2006;54(8):3033-40. Available from: https:// doi.org/10.1021/jf053167q

Uwah DF, Iwo GA. Effectiveness of organic mulch on the productivity of maize (Zeo mays L.) and weed growth. J Anim Plant Sci. 2011;21(3):525-30

Wauchope RD, Buttler TM, Hornsby AG, Augustijn-Beckers PWM, Burt JP. The SCS/ARS/CES Pesticide properties database for environmental decision making. Rev Environ Contam T. 1992;123:1-157. Available from: https://doi.org/10.1007/978-1-4612-2862-2_1

Wieclo G. Sequential herbicide treatments for goosegrass control in Bermuda grass (Cynodon dactylon) turf. Weed Technol. 2000;14(4):686-91. Available from: https://doi.org/10.1614/0890-037 X(2000)014[0686:SHTFGE]2.0.C0;2 